\title{
Investigating the Challenges of English Language Teachers in the EFL Class: In Case of Six Schools in Merti Woreda, Ethiopia
}

\author{
Eshetu Bekele Melkie \\ College of Social Science and Humanities, Dire Dewa University, Dire Dewa, Ethiopia
}

\begin{abstract}
This study was conducted in 6 different schools in the Oromiya Region, Arsi Zone, Merti Woreda, Ethiopia. The objective of this study was to in remote woredas schools. In line with this study, the researcher is investigating about language teaching facilities in the school, to assess the EFL classroom situation to teach English, to explore the challenges teachers face in the school in teaching English, and to suggests some ways of coping with them. The required data for the study were collected using a questionnaire, and interviews from 25 teachers. Then the data were analyzed and the study revealed that the teachers are exposed to challenges like lack of training, large class size, lack of teaching facilities, lack of supplementary materials, and the fixed arrangement of desks. The study also identified the students' poor language background and lack of encouragement leads teachers not to improve their professional skill in teaching English in EFL class are the identified challenges.
\end{abstract}

Keywords: EFL- English as a foreign language

DOI: $10.7176 / \mathrm{JEP} / 11-34-04$

Publication date: December $31^{\text {st }} 2020$

\subsection{Background of the study}

Now a day many countries use the English language for several reasons and countries concern it in their educational curriculum. Braine (1999) states, the English language has been widely used and considered as the universal language. Currently, the English Language has been playing a critical role in the Ethiopian different level of educational institutions. Ethiopian Ministry of Education (2005) describes that English is a corner stone in the development of Ethiopians commerce, communication systems, technology, and education. Therefore, English is used in several Ethiopian educational institutions as a compulsory subject in primary schools, and used as the language of instruction in high schools, preparatory schools, and in higher educational commissions.

In teaching English as foreign language teachers are expected to have interest, motivation, and good knowledge to teach English in EFL class right from the primary level to higher educational institutions. However, teachers face many problems in teaching English in the EFL class. For example, students have little ability to express themselves, overcrowded classes, and lack of sufficient books and facilities concerning supplementary materials. Therefore, many English Language teachers have been complaining about teaching English in such circumstances.

The researcher wants to highlight the investigation of teacher challenges towards the challenges of teaching English in EFL class, which is very important because it strongly influences our countries future development and good relationship with this globalized world, and teachers often engage in activities that allow students to be successful. Teachers' mental satisfaction has been being the most critical factor for success within teaching language environments. Bhallah, Jajoo, Kalantri (2002) express teaching as an art and the quality of teaching depends on the love, dedication, and devotion of the teacher towards the subject of the knowledge. The quality of any teaching program cannot rise above the quality of its teachers. A teacher is responsible for influencing a student's learning of the subject. This research may help teachers to develop the student's English language ability and it will show the most popular difficulties that teachers encounter while teaching English in EFL classes. Therefore, the researcher concentrated on the difficulties that encounter teachers in six schools.

\subsection{Statement of the Problem}

In Ethiopia today some English teachers were anxious about teaching English because they lack many facilities and a good teaching-learning environment in EFL classes. This means the shortage of teaching materials and teaching aids in the classroom setting affects the implementation and outcomes of teaching and this demotivates teachers, the objectives of teaching and learning English have not been satisfactorily met, and the number of students at every level are not able to use the content they learn where it is needed to be implemented. These problems are critical cases that need to be studied in-depth to get the solution.

The researcher is motivated to do this research because many of his colleagues usually complained about different challenges in teaching the English language in EFL class. The experiences of teachers and the results of various studies show that there are many problems that challenging teachers in teaching English in schools. For example, Omid T. and Ali A. (2012) made a study about An Investigation into the Problems of Teaching and Learning English their findings describe that numerous problems regarding the teachers, the learners, the textbooks and the methods were revealed, school libraries are not well equipped to be of service for the learners of English, 
classrooms are poor in terms of facilities and physical conditions, the English textbooks are not suitable for the students' level of proficiency, and the Ministry of Education does not honor the hard-working teachers, and many more ideas are discussed. Besides, Ayah I. \& Norma N.(2016) did a study on Difficulties that English Teachers Encounter while Teaching Listening Comprehension and Their Attitudes towards them; their study found that there were problems related to the teaching environment and availability of resources and teaching aids.

Finally, the abstract nature of learning necessitates constant research in the field to find solutions to questions and difficulties language educators face. Thus, the constant change and development in language teaching methods are meant to accommodate new findings in the field. Also, the willingness and motivations of teachers matter language teaching. Inappropriate availability of teaching materials, teaching aids, and classroom lead to difficulties in teaching which in turn negatively affect learners. (Salomon 1998). Therefore, this study was an attempt to find the challenges that affect teachers in teaching English in the EFL class.

\subsection{Objectives of the Study}

The main purpose of this study is to:

-To investigate about language teaching facilities in the school.

-To assess the EFL classroom situation to teach English.

-To explore the challenges teachers face in the school in teaching English, and to suggests some ways of coping with them.

\subsection{Research questions}

- What facilities are not available in the school at the time of teaching English?

-To what extent EFL classrooms are equipped to teach English?

- What are the challenges teachers face in teaching English?

\subsection{Significance of the Study}

This study has the benefits to investigate if the school has suitable language teaching facilities, to understand how classes are furnished to teach English, and, to identify the major challenges teachers face in the school in teaching English and used to suggest some techniques of coping from them. Therefore, this study will help education officials and other concerned bodies to take into account teachers' challenges which can influence the teaching and learning process. Then, things will be easy to give a solution for education officials and other bodies that recognize the constraints that exist in school. This study may also be used as a basis for future studies in the area.

\section{Review of related literature}

\subsection{English Language Teaching in Ethiopia}

The history of English language teaching goes to the introduction of modern education into the country during the regime of Menilik II. As it is mentioned in Meseret (2012) emperor Menelik and his advisors began to understand that the traditional education system did not contribute much to the needs and aspiration of the majority of Ethiopians towards development (Lulsseged, 1969). This realization of the drawback of traditional education by the Emperor eventually gave rise to the need for modern education. Later, Emperor Menelik II opened doors to the progress and development possible through modern education. Since the introduction of modern education in the country, English has been instructed as a subject beginning from the elementary level and used as a medium of instruction at the secondary and tertiary levels.

English is profoundly prized as a language which may offer access to advanced education and worldwide chance. The English language plays a significant role in Ethiopia educational system. Especially, at the secondary and tertiary levels, English is a key to all subjects. This means that Ethiopian students need to attain a reasonable degree of mastery of the English language to successfully respond to their academic demands. However, in implementing English language the English teachers have been exposed for different challenges; therefore, this study tried to have detailed concern of the study about challenges of the English language teachers in teaching English, and many works of literature are discussed in detail.

\subsection{Meaning of the Word Challenge}

In different English language dictionaries, the word challenge has many meanings in different contexts, but the researcher used only the meaning which goes with the theme of this study from the Oxford English dictionary. Therefore, challenge means according to this study a call to someone to participate in a competitive situation or fight to decide who is superior in terms of ability or strength.

\subsection{Challenges Affecting English Teachers in Different Educational Contexts}

Many challenges emerged as affecting large numbers of teacher's indifferent educational contexts. For example, facilities in the classroom, motivation, and interest of teachers, teaching large classes, and discipline connecting 
to large class sizes. Importantly, some of these challenges are challenges that they are seen in most Ethiopian schools. The situation is especially serious in poor or rural areas. In many EFL contexts, particularly in rural areas, children may struggle to understand the relevance of learning English as they have little contact with speakers of the language (Ho, 2003; Li, 1998). Having highlighted the key challenges identified in the literature of study are presented as follows.

\subsubsection{Teachers Training}

Evidence from literature confirms the view that the teacher is the most critical participant in educational reform, particularly in one that touches on what goes on in the classrooms (Mundy, 2008). However, their training and innovative skills is a necessary but not sufficient condition for effective learning. This means teachers are not given the chance to upgrade themselves using different opportunities like workshop training and in-service trainings. As federal democratic republic of Ethiopia Education and training policy (1994) describes various steps will be taken to promote incentives to motivate teachers especially to those assigned in hardship areas, but this is not practically implemented and it is still a major complaint of teachers.

\subsubsection{Language Policy}

In the lower primary, there is a mismatch between language policy and the actual practice in my context. This creates anxiety and stalls effective classroom participation (Kodero et al., 2011). Also the federal democratic republic of Ethiopia Education and training policy (1994) describes that the necessary steps will be taken to strengthen language teaching at all levels, but practically not implemented. Although the curriculum is designed to be covered in a year; teachers are under pressure from the district education officers to complete it by the given academic schedule given from the ministry of education. This supposes that the teachers have ultimately delayed to create effective classroom practices;

\subsubsection{Class Size}

In many parts of the world, large classes are a common challenge (Ho, 2003; Shamim, 2012; Wedgwood, 2007), causing teachers to believe it is difficult or impossible to introduce learner-centered teaching because, for example, they cannot closely monitor students' language use $(\mathrm{Li}, 1998)$ or introduce pair work and group work (Hoque, 2009). Other related constrained resources include overcrowded buildings, noisy and unsafe environments, and poorly ventilated classrooms impeding effective teaching. The introduction of free primary education witnessed an influx of learners in the primary schools thus increasing the class size (Muchiri, 2009). The challenges of handling large classes compounded by the acute shortage of teachers put a strain on the teachers' ability to provide quality language work to the learners because the teacher-learner ratio is not proportional. Moreover, the policy demands of inclusive learning pose a challenge in the already swollen classrooms since it compromises individual attention because of the diverse needs of the learners (Glasson, 2009).

\subsubsection{Resources}

There is limited access of resources in different English classrooms. For example, the pupil/textbook ratio is a significant measure of effective teaching because pupils heavily rely on textbooks. Therefore, in a constrained textbook environment, it is difficult for a teacher to implement effective practices. Even if we look the global prevalence of early English learning, it is a matter of concern that in many countries appropriate books are either not available (Hoque, 2009; Y. Hu, 2007; Mathew \& Pani, 2009) or are not used in the classroom(Inal, 2009; Nunan, 2003). Other resources may also be unavailable in primary schools.

In Li's (1998) study South Korean teachers complained that there was insufficient funding for the equipment and facilities needed for learner-centered teaching, a point also made by_Inal (2009) for Turkish teachers. While the technology to support English teaching has developed greatly in recent years, teachers have not always been able to access its benefits. In Ethiopian context the federal democratic republic of Ethiopia Education and training policy (1994) describes in order to promote the quality relevance and expansion of education, due attention will be given to the supply, distribution and utilization of educational materials, educational technology and facilities, but it is still in problem in its implementation.

\subsubsection{Students' language skill ability}

Another potential challenge for teachers concerns the level of English they require from their students. Many teachers believe that teaching English demands particular classroom procedures, such as teaching in the target language, which causes anxiety and leads to teachers' questioning their competence, particularly their speaking and listening skills (Kuchah, 2009). From this students are expected to have some ability and skill to communicate with their teacher unless it is a headache for the teacher to teach with the target language.

\section{Research Methodology}

\subsection{Research Design}

Research design can be defined as the work plan that specifies the type of data to be collected to answer the research questions and the methods needed to collect the data. This study was applied to find out the challenges of English teachers in remote primary, secondary, and preparatory schools. Therefore, a descriptive research method was chosen as it is used to specify or describe a phenomenon without experimenting (Selinger and Shohamy, 1989). 


\subsection{Research Settings}

The data collection was applied at, Oromiya region, Arsi zone, Merti woreda, Abomsa town, and neighborhood schools. The whole schools' common woreda is far about $200 \mathrm{~km}$ from capital Addis Abeba.

\subsection{Target Population}

The subjects of this study were 10 English language teachers from two primary schools (1-8), 13 English language teachers from three high schools, and 2 English teachers from one preparatory school totally 25 English teachers are the subjects of this study. To get these subjects the whole English teachers are taken from their school depending on availability sampling method. These schools were selected because their location is close for the working area of the researcher and suitable for collecting data for the study.

Table 3.1 Name, Number, and level of schools

\begin{tabular}{|l|l|l|l|}
\hline No. & Name of school & SCHOOLS TYPE & No. of teachers \\
\hline 1 & Abomsa & Preparatory & 2 \\
\hline 2 & Abomsa & High school & 9 \\
\hline 3 & Gara Gora & High school & 2 \\
\hline 4 & Elo & High school & 2 \\
\hline 5 & Abomsa No.1 & Primary 1-8 & 5 \\
\hline 6 & Abomsa No. 2 & Primary 1-8 & 5 \\
\hline \multicolumn{2}{|l|}{ Total } & 25 \\
\hline
\end{tabular}

Table3.1. Teachers experience and qualification

\begin{tabular}{|l|c|l|l|}
\hline Qualification & Number & Experience & Number \\
\hline Dipploma & 9 & $1-5$ years & 5 \\
\hline Degree & 19 & $6-10$ years & 5 \\
\hline MA & - & $11-15$ years & 7 \\
\hline \multirow{2}{*}{ Total } & 28 & 16 and above & 8 \\
\cline { 2 - 4 } & & Total & 25 \\
\hline
\end{tabular}

\subsection{Sampling Technique}

English teachers are the primary sources of the study. To get the sample the whole English teachers are taken from their school depending on availability sampling method. Therefore, 25 English teachers are participants as a sample.

\subsection{Data collection Tools}

This research used a questionnaire because it makes the respondent free in answering the questionnaire. As, Seliger and Shohamy (1989:172) define it as printed forms of data collection, which include questions or statements to which the subject is expected to respond often anonymously. And also interview is used as the other data collection instrument and a valuable research method because it allows the researcher to explore data on understanding, opinions, what people remember doing, attitudes, feelings and the like. A triangular approach was used to collect data from a total of 25 English language teachers.

\subsection{Data Collection Procedure}

Since the quality of any research depends largely on the quality of the data collected and the data collection procedure, this study has employed multiple procedures to collect data from the sample subjects. Questionnaires were distributed and filled by 25 of the teachers. Among those teachers, 10 were interviewed.

\subsection{Methods of Data Analysis}

Data were gathered to explore what challenges English teachers face in the classroom in teaching English. Merriam (1998:178) describes that data analysis is to make sense of the data and to make meaning. Therefore, this data was gathered and analyzed using the following procedures. The data analysis process consisted of both qualitative and quantitative methods. The qualitative data was organized and analyzed descriptively with the help of paragraphs. The quantitative data were analyzed using Likert-type item analysis. The data gathered using questionnaires were tallied, tabulated, and analyzed using statistical techniques. The data obtained from the interview was transcribed, analyzed, interpreted, and coded. Finally, the results of the questionnaire and interview were triangulated.

\section{Results}

\subsection{Analysis of the Data}

Seliger and Shohamy (1989:201) define the process of data analysis as organizing, summarizing, and synthesizing the data so as to arrive at the results and conclusions of the research. Therefore, this part of the study presents and 
discusses the analysis and results, which investigates the challenges that English teachers encounter in teaching English in the EFL class. The collected data were analyzed and interpreted as follows: all the data from the questionnaire were tallied, counted, and registered as the frequency that showed the number of respondents. Then questions and their results are presented in tabular form and calculated in percentages.

\section{The Questionnaire}

In this part, the questionnaire items are presented with their respective interpretation and discussion. The respondents were asked to choose among choices, which indicate their agreement or disagreement by choosing Yes and No with the given statements.

Table4.1. Problems related to teachers and teaching facilities

\begin{tabular}{|c|c|c|c|c|c|}
\hline No. & \multicolumn{2}{|c|}{ Items of Questionnaire } & \multicolumn{3}{c|}{ Responses } \\
\cline { 3 - 6 } & & Yes & No & Total \\
\hline $\mathbf{1}$ & English teachers are not motivated by different & Freq. & $\mathbf{2 5}$ & - & $\mathbf{2 5}$ \\
\cline { 3 - 6 } & incentives like professional training and workshops. & $\%$ & $\mathbf{1 0 0} \%$ & - & $\mathbf{1 0 0} \%$ \\
\hline $\mathbf{2}$ & My experience in teaching English is not enough & Freq. & - & $\mathbf{2 5}$ & $\mathbf{2 5}$ \\
\cline { 3 - 6 } & & $\mathbf{\%}$ & - & $\mathbf{1 0 0} \%$ & $\mathbf{1 0 0} \%$ \\
\hline $\mathbf{3}$ & Methods of teaching in students text are not suitable & Freq. & $\mathbf{2 0}$ & $\mathbf{5}$ & $\mathbf{2 5}$ \\
\cline { 3 - 6 } & & $\mathbf{\%}$ & $\mathbf{8 0} \%$ & $\mathbf{2 0} \%$ & $\mathbf{1 0 0} \%$ \\
\hline
\end{tabular}

With regard to English teachers are not motivated by different incentives like professional training and workshops the results in indicates that $25(100 \%)$ of the teachers choose the answer Yes which means that they are not motivated by pieces of training and workshops which can upgrade their ability and aware them with new and modern methods in teaching English and as can be vividly seen from question 2 item about if their experience in teaching English is not enough or not $25(100 \%)$ teachers answered No which means their experience is enough to teach the grade level that they are teaching and all of them are confident about their teaching experience. As can be clearly observed, from the idea under question three $20(80 \%)$ of the teachers said the methods of teaching in students' text are not suitable, but only $5(20 \%)$ of the respondents accept that the methods used in the students textbook is suitable for teaching English in EFL class .

Table4.2. Problems related teaching facilities

\begin{tabular}{|c|c|c|c|c|c|}
\hline \multirow[t]{2}{*}{4} & \multirow[t]{2}{*}{ Electricity supplies are always available } & Freq. & 15 & 10 & 25 \\
\hline & & $\%$ & $60 \%$ & $40 \%$ & $100 \%$ \\
\hline \multirow[t]{2}{*}{5} & \multirow{2}{*}{$\begin{array}{l}\text { There are not well-equipped rooms to teach English at } \\
\text { School. }\end{array}$} & Freq. & 25 & - & 25 \\
\hline & & $\%$ & $100 \%$ & - & $100 \%$ \\
\hline \multirow[t]{2}{*}{6} & \multirow{2}{*}{$\begin{array}{l}\text { The classroom is uncomfortable for group work because } \\
\text { of the arrangement of desks and the size of the class }\end{array}$} & Freq. & 21 & 4 & 25 \\
\hline & & $\%$ & $84 \%$ & $16 \%$ & $100 \%$ \\
\hline \multirow[t]{2}{*}{7} & \multirow{2}{*}{$\begin{array}{l}\text { There aren't enough supplementary materials in the } \\
\text { school for teaching English }\end{array}$} & Freq. & 17 & 8 & 25 \\
\hline & & $\%$ & $68 \%$ & $32 \%$ & $100 \%$ \\
\hline \multirow[t]{2}{*}{8} & \multirow{2}{*}{$\begin{array}{l}\text { Integrating technologies for teaching English is } \\
\text { implemented. }\end{array}$} & Freq. & 13 & 12 & 25 \\
\hline & & $\%$ & $52 \%$ & $48 \%$ & $100 \%$ \\
\hline \multirow[t]{2}{*}{9} & \multirow[t]{2}{*}{ Students and teacher's book is available in the school } & Freq. & 23 & 2 & 25 \\
\hline & & $\%$ & $92 \%$ & $\mathbf{8 \%}$ & $100 \%$ \\
\hline \multirow[t]{2}{*}{10} & \multirow[t]{2}{*}{ Authentic materials are not available. } & Freq. & 22 & 3 & 25 \\
\hline & & $\%$ & $88 \%$ & $12 \%$ & $100 \%$ \\
\hline
\end{tabular}

$15(60 \%)$ of the teachers indicated that their school has a problem with access to electricity; however, only $10(40 \%)$ of the respondents reported that there is no problem in supply of electricity in their school. As is evident from question 5 all of the teachers $25(100 \%)$ expressed their agreement that there are not well equipped rooms in the school to teach English. As it is possible to see from the response to item 6 majority of the teachers 21(84\%) answered that the classrooms in their school are not comfortable to form small groups and large groups because of the arrangement of the desks and the size of a classroom; however, only 4(16\%) respondents agree that their school has comfortable classrooms to form small groups and large groups.

From the results for question 7 above $17(68 \%)$ of the teachers answered that enough supplementary materials are not available; but some teachers $8(32 \%)$ disagree that there are enough supplementary materials in the school for teaching English. A look at data from question 8 results 13(52\%) of the teachers indicate that technologies integrated for the purpose of teaching in their school; in contrast, $12(48 \%)$ of the teachers agree that technologies are integrated in their school to teach English. From the result of data question 9, majorities 23(92\%) of the teachers show that there is no lack of student and teachers book, but $2(8 \%)$ of the respondents described that there is lack of student and teachers book to teach English in their school. Regarding this idea Richards and Rodgers (2001) say that text books have positive and vital roles to play in the day to day language teaching and their importance 
has become even greater and larger from time to time. They are also critical ingredients in learning the intended curriculum. From results of Question 10 most of the teachers $22(88 \%)$ of the samples answered that there are no authentic materials in the school for teaching English, but 3(12\%) answered that there are authentic materials in the school for teaching English.

\subsubsection{Analysis of the Interviews}

The semi-structured interview was aimed to get teachers' views of the limitations faced them in teaching English. It attempted to eradicate the possible problems English language teachers faced in the EFL class. The data gathered through interviews primarily focuses on the existing problems with the teachers. For an in-depth analysis of the interviews, ten English language teachers were selected. For analysis of interview, the teachers are referred by randomly given numbers $\mathrm{T} 1, \mathrm{~T} 2, \mathrm{~T} 3 \ldots \mathrm{T} 10$.

Q1. Does your school have enough facilities for teaching English in the EFL class?

All of the teachers (T1...T10) reported that there is absence of facilities in their corresponding schools and delayed them from teaching English, commented that there is no contemporary technological devises are used in the school. For example, they mentioned that there is no duplicating machine in the school and its scarcity made it difficult for teachers to prepare and present the teaching materials for teaching English, but there are some computers for the information technology department but English language teachers are not allowed to use it for teaching English.

Q2. Is there electric power in your school often?

(T1, T2, T3, T5, T6, T7, T9, and T10) replied that there is no electricity and it makes impossible to teach students even with plasma television program. In contrast (T4 and T8) expressed that there is no problem in electricity supply.

Q3. Is the class size in your school comfortable to teach English and to arrange group?

Most of the teachers (T1 T2, T3, T6, T7, T8, and T9) seriously complained that the class size in their school is not comfortable and it is a major obstacle. The teachers told that they are unable to control such a large group of students to make activities in groups or pairs. In addition to the arrangement of the chairs are also their problems because they are fixed at their position and the width of the class by itself makes it difficult to rearrange. (T4, T5, T10) told that size of the class not matter their teaching process because their students are less in number and it never makes the students to feel bored and that they are easily attend their students, evaluating students' performance, totally these three teachers told that they had no difficulty in reaching all the students while they are discussing in their groups.

Q4. What materials are commonly available in your class at the time you teach English?

All of the teachers (T1...T10) answered that they have a blackboard and chalk, and sometimes plasma television for teaching English in EFL class. It is not supported by other additional technological teaching materials.

Q5. Do you believe that your students level of the English language ability enough?

Depending on (T1, T3, T5, T6, T8, T9, and T10) response the level of most students language ability is not good and they have inadequate practice of the language at their present grade level. In addition they described that students feel uncomfortable when they are asked by the teacher to participate in a dialogue because of their poor language ability. In contrast, (T2, T4, and T7) responded that the students have good level of the language ability and adequate practice of the language at their grade level.

Q6. Are there enough supplementary materials to teach English in your school?

The whole teachers (T1...T10) told that lack of supplementary materials is a common problem for teachers in their school. Teachers told that some students get supplementary materials using their own effort but at the side of school there is financially a great problem to fulfill the need of these materials.

To summarize, from the data of interview there were powerful barriers for teachers to teach English in the EFL class. Most of the limitations they faced were lack of resources (facilities), electric power, large class size, students' English abilities, and lack of supplementary materials were the most common problems of teachers in teaching English.

\section{Conclusion}

Based on the finding of the study presented so far the following conclusions have been done.

1. In teaching English teachers mostly have the limitations of lack of resources (facilities) are seen.

2. To use plasma television for teaching English in most schools there is electric power problem is one issue.

3. It is observed that large class size is the most difficulty in schools under this study for teachers to teach English.

4. Students' English abilities for their grade level are a finding which needs solution in EFL class.

5. Finally, there are also lack of supplementary materials which are the most common problems of teachers in teaching English in most schools under this study.

Bibliography

Ayah I. \& Norma N. (2017). Difficulties that English Teachers Encounter while Teaching Listening 
Comprehension and Their Attitudes towards Them: Published by Canadian Center of Science and Education. Bhalla, A, Jajoo, U., \& Kalantri, C. (2002). Attitudes of Teachers towards Teaching. Associates Physician India. Braine, G. (1999). Non-native Educators in English Language Teaching. Lawrence Erlbaum Associates: New York. prentice Hall Inc. Englewood cliffs: New Jersey.

F. D. R. E. (1994). Education and Training Policy. Addis Ababa : St. George Printing Press

Glasson, T. (2009). Improving Student Achievement: A Practical Guide to Assessment for Learning. Carlton South, VIC: Curriculum Corporation.

Ho, W. K. (2003). English language teaching in Asia today: An overview. In W. K. Ho \& R. Y. L. Wong (Eds.), English language teaching in east Asia today: Changing policies and practices (pp. 1-32). Singapore: Eastern Universities Press.

Hoque, S. (2009). Teaching English in primary schools in Bangladesh: Competencies and achievements. In J. Enever, J. Moon, \& U. Raman (Eds.), Young learner English language policy and implementation: International perspectives.

Hu, Y. (2007). China's foreign language policy on primary English education: What's behind it? Language Policy. Reading, England: Garnet Education.

-Inal, D. (2009). The early bird catches the worm: The Turkish case. In J. Enever, J. Moon, \& U. Raman (Eds.), Young learner English language policy and implementation: International perspectives. Reading, England: Garnet Education.

Kodero, H. M. N., Misigo, B. L., Owino, E. A., and Simiyu, C. K. (2011). The salient characteristics of trained ineffective teachers in secondary schools in Kenya.

Kuchah, K. (2009). Early bilingualism in Cameroon: Where politics and education meet. In J. Enever, J. Moon, \& U. Raman (Eds.), Young learner English language policy and implementation: International perspectives (pp. 87-94). Reading, England: Garnet Education.

Li, D. (1998). "It's always more difficult than you plan and imagine": Teachers' perceived difficulties in introducing the communicative approach in South Korea. TESOL Quarterly,32, 677-703. doi: $10.2307 / 3588000$

Lulusseged Alemayehu. (1969). A descriptive analysis of the Administration of Education in transition in Ethiopia. ( Unpublished doctoral dissertation).

Merriam, S. B. (1998). Qualitative research and case study applications. San Francisco, CA: Jossey Bass.

Meseret Teshome. (2012). Instructors' and Students' Perceptions and Practices of Task-Based Writing in an EFL Context :Addis Ababa University.

MoE. (2005). Guidelines for English Language Enhancement for Our Teacher Education Institutions: A Set of Practical Guidelines to Help Promote the Use of English at Your Institution. Addis Abeba: MoE.

Muchiri, M. N. (2009). Papers on Language and Culture: An African Perspective. Nairobi: Authorhouse.

Mundy, K. E. (2008). Comparative and International Education: Issues for Teachers. Toronto; New York: Canadian Scholars' Press, Teachers College Press.

Nunan, D. (2003). The impact of English as a global language on educational policies and practices in the AsiaPacific region. TESOL Quarterly,37, 589-613. doi:10.2307/3588214

Omid T. \&Ali A.( 2012). An Investigation into the Problems of Teaching and Learning English in the Isfahan Province High Schools: Journal of Language Teaching and Research, Vol.3. (C) 2012 Academy Publisher

Pani, S. (2009). Issues in the implementation of teaching English for young learners (TEYL): A case study of two states in India. In J. Enever, J. Moon, \& U. Raman (Eds.), Young learner English language policy and implementation: International perspectives (pp. 113-120). Reading, England: Garnet Education.

Richards, C and Rodgers, T. (2001). Approaches and Methods in Language Teaching. New York: Cambridge University Press.

Salomon, A. M. (1998). Communicative grammar teaching: A problem for and a message from international teaching assistants. Foreign Language annuals.

Selinger, H. W., and E. Shohamy. 1989. Second Language Research Methods. Oxford: Oxford University Press.

Shamim, F. (2012). Teaching large classes. In A. Burns \& J. C. Richards (Eds.), The Cambridge guide to pedagogy and practice in second language teaching (pp. 95-102). New York, NY: Cambridge University Press.

Wedgwood, R. (2007). Education and poverty reduction in Tanzania. International Journal of Educational Development,27, 383-396. doi:10.1016/j.ijedudev.2006.10.005 